\title{
DEVELOPMENT AND VALIDATION OF HPLC/UV-PROCEDURES OF SECNIDAZOLE DETERMINATION IN BLOOD AND URINE
}

\author{
(c) O. Shovkova, L. Klimenko, Z. Shovkova, O. Mykytenko
}

\begin{abstract}
Mета. Система ВEPX-аналізатора MiLiChrome® A-02 широко використовується в українських лабораторіях судово-медичної токсикології. Мета - застосувати систему ВЕРХ-аналізатора для кількісного визначення секнідазолу в біологічних рідинах і провести валідацію розроблених методик.

Методи. Пробопідготовка крові і сечі здійснювалася трьома способами: 1) рідко-рідинна екстракція органічними розчинниками, щуо не змішуються з водою, 2) екстракція амфіфільними розчинниками і висолювання амоній сульфатом, 3) комплексне застосування рідко-рідинної екстракції органічними розчинниками, щуо не змішуються з водою, і амфіфільними розчинниками з наступним висолюванням. Умови хроматографування: колонка - $2 \times 75 \mathrm{mм}$, ProntoSIL 120-5-C18 AQ, 5 мкм; температура - 40 ${ }^{\circ} \mathrm{C}$; ивидкість потоку - 100 мкл/хв.; елюент $\mathrm{A}$ - 0,2 $\mathrm{M} \mathrm{LiClO}_{4}-0,005 \mathrm{M} \mathrm{HClO}_{4}$; елюент Б-ацетонітрил; режим елюювання - лінійний градієнт; детектування - УФ, 277 нм; об 'єм проби - 2 мкл.

Результати. Валідація всіх розроблених методик проводилась за такими параметрами, як специфічність, ступінь ізолювання, лінійність, правильність і преиизійність у варіанті методу стандарту. Результати аналізу показали відсутність піків з часом утримування, який співпадає з часом утримування секнідазолу, на хроматограмах blank-зразків для всіх варіантів способів пробопідготовки. Всі прочедури пробопідготовки показали високу ефективність ізолювання секнідазолу як для крові, так $і$ для сечі (на рівні $90 \%$ ). Всі розглянуті проиедури характеризуються прийнятними параметрами лінійності, within-run i between-run правильності і прещизійності.

Висновки. Розроблено комплекс ВЕРХ-методик кількісного визначення секнідазолу в крові і сечі. Проведено валідацію розроблених методик; застосування ізопропанолу в кислому середовищі оптимальне для пробопідготовки біологічних рідин
\end{abstract}

Ключові слова: секнідазол, високоефективна рідинна хроматографія, кров, сеча, пробопідготовка, валідація, метод стандарту

\section{Introduction}

Protozoan infections are parasitic diseases caused by organisms formerly classified in the Kingdom Protozoa [1]. They include such organisms as Entamoeba histolytica, Plasmodium falciparum, Giardia lamblia and Giardia intestinalis, Trypanosoma brucei and Trypanosoma cruzi, Trichomonas vaginalis, Toxoplasma gondii, Leishmania species, etc. [2]. Protozoan infections in animals may be caused by Coccidia and Besnoitia species [3]. The main group of medicines used for protozoan infections treatment is the derivatives of 5-nitroimidazole [4]. The most well-known drug from the group is metronidazole [4]; its activity was discovered by accident in 1962 [5] and it was not until the 1970s that metronidazole was popularized for treatment of infections caused by gram-negative or gram-positive anaerobes and protozoa [6].

2. Formulation of the problem in a general way, the relevance of the theme and its connection with important scientific and practical issues

Last years in animal husbandry and agriculture in EU countries metronidazole application is prohibited, and medical application is limited [7]. Therefore, other derivatives of 5-nitroimidazole are now at the forefront, especially substances with an extended duration of action and short-term application [8]. Secnidazole has the longest half-life among them (up to 25 hours), its maximum concentration in the blood $(20-50 \mu \mathrm{g} / \mathrm{ml})$ is achieved in $2-3$ hours, and significant concentrations in the blood (3-5 $\mu \mathrm{g} / \mathrm{ml})$ are fixed for $3-5$ days [9].
3. Analysis of recent studies and publications in which a solution of the problem are described and to which the author refers

High-performance liquid chromatography (HPLC) with different techniques detection is the most popular method used in analysis of secnidazole. HPLC/UVmethod in the range of $10-50 \mu \mathrm{g} / \mathrm{ml}$ was described for secnidazole determination (columns - Hypersil C18 $\varnothing 4.6 \times 250 \mathrm{~mm}, 10 \mu \mathrm{m}$ and Hypersil C18 $\varnothing 1.0 \times 250 \mathrm{~mm}$, $5 \mu \mathrm{m}$; mobile phase - the mixture of water (acidified with acetic acid to $\mathrm{pH}=3.5)$ and methanol (30:70); UVdetection - $310 \mathrm{~nm}$ ) [10]. Another HPLC/UV-conditions of secnidazole determination in meat was proposed (range - $1-20 \mu \mathrm{g} / \mathrm{ml}$, column - Diamonsil C18 $\varnothing 4.6 \times 250 \mathrm{~mm}, 5 \mu \mathrm{m}$; mobile phase (gradient mode) the mixture of water, acetonitrile and methanol; UVdetection - $320 \mathrm{~nm}$ ); secnidazole isolation was carried out by extraction with ethyl acetate [11]. It was proposed to determine secnidazole in human plasma by the method of $\mathrm{HPLC} / \mathrm{UV}$ in the range of $1-40 \mu \mathrm{g} / \mathrm{ml}$ (column ODS - $\varnothing 4.6 \times 250 \mathrm{~mm}, 5 \mu \mathrm{m}$; mobile phase - the mixture of acetonitrile and sodium acetate (10:90); UV-detection $276 \mathrm{~nm}$ ); secnidazole isolation was carried out by extraction with methylene chloride in alkaline medium [12]. Li $\mathrm{X}$. and co-authors [13] also developed the HPLC/UVprocedure for secnidazole determination in human plasma (range $-0.1-25 \mu \mathrm{g} / \mathrm{ml}$, column - Diomand C18 $\varnothing 4.6 \times 250 \mathrm{~mm}, 5 \mu \mathrm{m}$; mobile phase - the mixture of acetonitrile and $0.005 \mathrm{M}$ sodium acetate (30:70); UVdetection $-319 \mathrm{~nm}$ ); secnidazole isolation was carried 
out by extraction with ethyl acetate [13]. Two HPLC/UV-procedures more was described for secnidazole quantification in human plasma with application of such columns as Dikma ODS-C18 [14] and Bondex C18 [15]; mobile phase was the mixture of water and acetonitrile in different ratio (UV-detection - $320 \mathrm{~nm}$ ); the range of application was $0.25-50 \mu \mathrm{g} / \mathrm{ml}$ and $0.5-50 \mu \mathrm{g} / \mathrm{ml}$ respectively. The method of HPLC/MS/MS was described for secnidazole determination in bees wax [16] and muscle samples [17]; such columns as Luna PFP $\varnothing 2 \times 150 \mathrm{~mm}$, $3 \mu \mathrm{m}[16]$ and Kinetex XB-C18 $\varnothing 2.1 \times 100 \mathrm{~mm}, 1.7 \mu \mathrm{m}$ [17] was used; mobile phase was the mixture of $0.01 \%$ acetic acid in acetonitrile and $0.01 \%$ acetic acid in water [16] and the mixture of $0.01 \%$ formic acid in acetonitrile and $0.01 \%$ formic acid in water [17]; the range of application was $0.2-20 \mu \mathrm{g} / \mathrm{ml}$ and $0.5-10 \mu \mathrm{g} / \mathrm{ml}$ respectively.

\section{The field of research considering the general problem, which is described in the article}

The system of HPLC-analyzer MiLiChrome ${ }^{\circledR}$ A02 [18] is widely used in Ukrainian laboratories of forensic toxicology. Previously [19] we developed the
HPLC/UV-procedure for secnidazole quantitative determination using this chromatographic system, carried out its validation by model solutions and showed the possibility for application in analytical toxicology.

\section{Formulation of goals (tasks) of article}

The purpose of present work is to apply the described HPLC/UV-procedure for secnidazole quantitative determination in biological liquids (whole blood and urine) using different types of sample preparation procedures, carry out its validation by matrix samples in the variant of the method of standard and prove the acceptability of application for forensic toxicology.

6. Presentation of the main research material (methods and objects) with the justification of the results

Secnidazole was of pharmacopoeial purity (99.7\%) and obtained from the pharmaceutical company TOV «Zdorovye».

The procedure of calibration and model samples preparation of blood and urine is presented on Fig. 1.

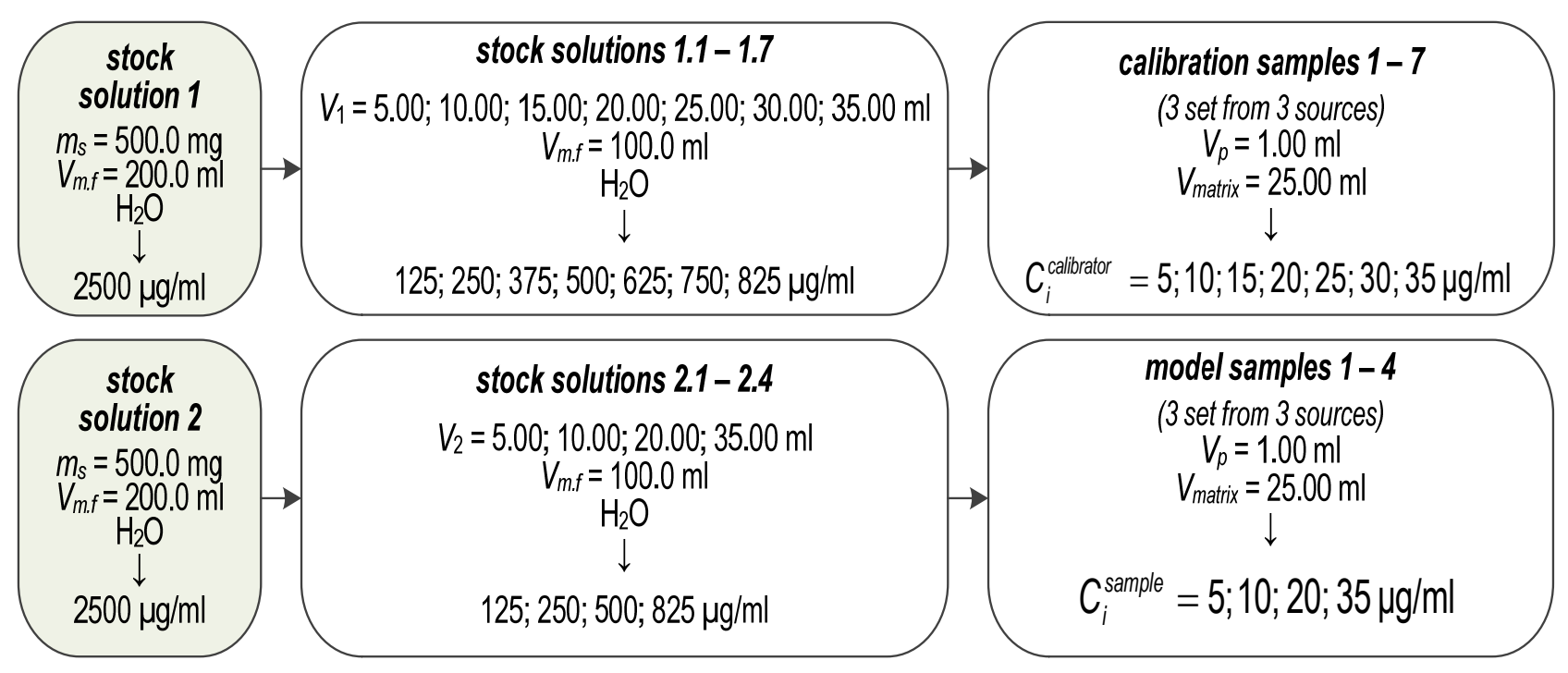

Fig. 1. The order of samples preparation for validation of secnidazole determination procedures in blood and urine

The stock solutions $3(100 \mu \mathrm{g} / \mathrm{ml})$ were prepared by dissolving $50.0 \mathrm{mg}$ of secnidazole in $0.01 \mathrm{~mole} / \mathrm{l}$ hydrochloric acid solution and the solutions were diluted to $500.0 \mathrm{ml}$ with the same solvent. The reference solution $(8 \mu \mathrm{g} / \mathrm{mL})$ was prepared by diluting $4.00 \mathrm{ml}$ of the stock solution 3 to $50.0 \mathrm{ml}$ with $0.01 \mathrm{~mole} / 1$ hydrochloric acid solution.
The stock solution 3 was diluted with $0.01 \mathrm{~mole} / 1$ hydrochloric acid solution to prepare the model solutions $1-4$ having concentrations of $2 ; 4 ; 8$ and $14 \mu \mathrm{g} / \mathrm{ml}$ respectively.

The procedures of sample preparation of biological liquids for secnidazole determination are presented on Fig. 2. 


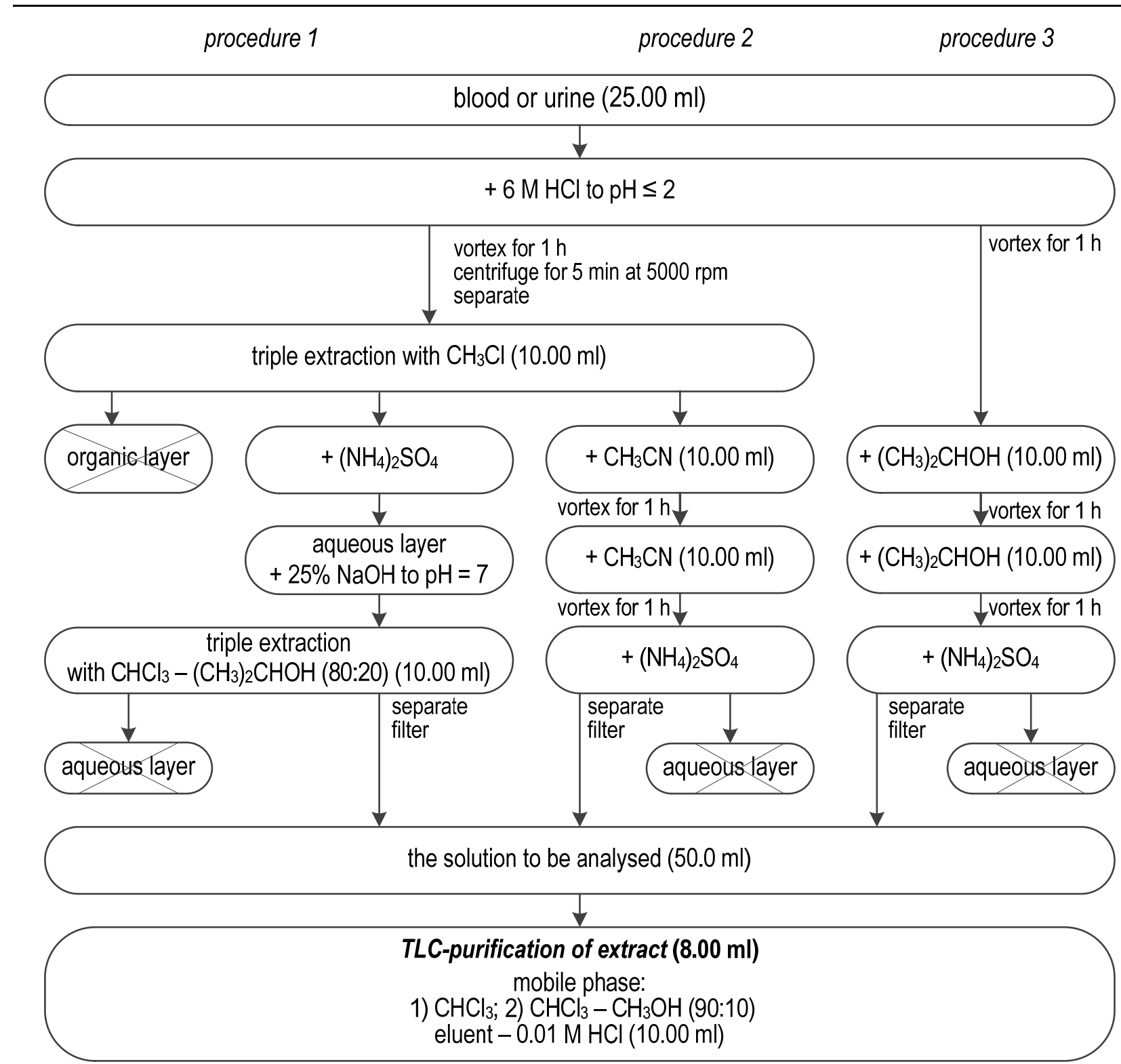

Fig. 2. The main stages of the procedures of sample preparation of blood and urine for secnidazole determination by the method of HPLC/UV

Procedure 1: $25.00 \mathrm{ml}$ of blood or urine was acidified with $6 \mathrm{M}$ hydrochloric acid solution to $\mathrm{pH} \leq 2$. The mixture was vortexed for 1 hour, then centrifuged for 5 minutes at $5000 \mathrm{rpm}$. The supernatant ( $\mathrm{pH}$ should be less than 2) was extracted with $10.00 \mathrm{ml}$ of chloroform triply (chloroform extracts were separated and removed).

The aqueous layer was salted-out by adding ammonium sulphate till stopping its dissolution, then neutralised with $25 \%$ ammonia solution and extracted with $10.00 \mathrm{ml}$ of the mixture of chloroform and 2-propanol (80:20) triply. The obtained organic extracts were separated, filtered through the paper filter with $1 \mathrm{~g}$ of sodium sulphate anhydrous into the measuring flask with the capacity of $50.0 \mathrm{ml}$, and diluted to the volume with chloroform.

Procedure 2: $25.00 \mathrm{ml}$ of blood or urine was acidified with $6 \mathrm{M}$ hydrochloric acid solution to $\mathrm{pH} \leq 2$. The mixture was vortexed for 1 hour, then centrifuged for 5 minutes at $5000 \mathrm{rpm}$. The supernatant $(\mathrm{pH}$ should be less than 2) was extracted with $10.00 \mathrm{ml}$ of chloroform triply (chloroform extracts were separated and removed).
The aqueous layer was processed twice with $10.00 \mathrm{ml}$ of acetonitrile and vortexed for 1 hour each time. After adding $2 \mathrm{~g}$ of ammonium sulphate the mixture was filtered through the paper filter (wetted with acetonitrile) into the separating funnel and salted-out by adding ammonium sulphate till stopping its dissolution. Top organic layer was separated, filtered through the paper filter with $1 \mathrm{~g}$ of sodium sulphate anhydrous into the measuring flask with the capacity of $50.0 \mathrm{ml}$, and diluted to the volume with acetonitrile.

Procedure 2: $25.00 \mathrm{ml}$ of blood or urine was acidified with $6 \mathrm{M}$ hydrochloric acid solution to $\mathrm{pH} \leq 2$. The mixture was vortexed for 1 hour, then centrifuged for 5 minutes at $5000 \mathrm{rpm}$. The supernatant $(\mathrm{pH}$ should be less than 2) was processed twice with $10.00 \mathrm{ml}$ of acetonitrile and vortexed for 1 hour each time. After adding $2 \mathrm{~g}$ of ammonium sulphate the mixture was filtered through the paper filter (wetted with acetonitrile) into the separating funnel and salted-out by adding ammonium sulphate till stopping its dissolution. Top organic layer was separated, filtered through the paper filter with $1 \mathrm{~g}$ of 
sodium sulphate anhydrous into the measuring flask with the capacity of $50.0 \mathrm{ml}$, and diluted to the volume with acetonitrile.

The model and calibration samples, and also blank-samples were analysed for each procedure of sample preparation; the blank-samples were prepared in the following way: 5 samples $(10.00 \mathrm{ml})$ of the matrix obtained from the different sources, in $1.00 \mathrm{ml}$ of distilled water was added into them.

The chromatographic conditions:

- device - high pressure liquid chromatograph MiLiChrome ${ }^{\circledR}$ A-02 (EcoNova, Russia);

- software - Analitika-Chrom ${ }^{\circledR}$ (Analitika SPF, Ukraine);

- column - $\varnothing 2 \times 75$ mm, ProntoSIL 120-5-C18 AQ, $5 \mu \mathrm{m}$ (BISCHOFF Analysentechnik und -geräte GmbH, Germany);

- temperature $-40^{\circ} \mathrm{C}$;

- flow rate $-100 \mu \mathrm{l} / \mathrm{min}$;

- Eluent A - 0.2 $\mathrm{M} \mathrm{LiClO}_{4}-0.005 \mathrm{M} \mathrm{HClO}_{4}$;

- Eluent B - acetonitrile;

- elution mode - linear gradient (from $5 \%$ to $100 \%$ Eluent B for $40 \mathrm{~min}$, then $100 \%$ Eluent B for $3 \mathrm{~min}$ );

- detection - UV, $277 \mathrm{~nm}$;

- volume of injection $-2 \mu$ l.

Each solution to be analysed was chromatographed 3 times or, as required, more following the requirements to repeatability of peaks areas $S$ for replicate injections offered by us [20] - the relative standard deviation of the mean $R S D_{\text {nоm }}$ calculated towards the nominal value of peak area $S_{\text {nom }}$ should not exceed:

$$
\begin{aligned}
& R S D_{\text {nот }}=\frac{s}{S_{\text {nom }}} \cdot 100 \% \leq \frac{0.1 \cdot \max \Delta_{A s} \cdot \sqrt{n}}{t(95 \%, n-1)}= \\
& =\left\{\begin{array}{ll}
1.47 \% ; & n=3 \\
1.88 \% ; & n=4 \\
2.22 \% ; & n=5 \\
2.52 \% ; & n=6
\end{array}\right\} ; \\
& S_{\text {nom }}=S_{\min }=\bar{S}_{25 \%},
\end{aligned}
$$

where $\max \Delta_{A s}$ - is the extreme relative uncertainty of the procedure of analysis, $\max \Delta_{A s}=20 \%[21] ; \bar{S}_{25 \%}-$ the mean peak area obtained when analysing the respective solutions with the analyte concentration corresponded to the point of $25 \%$ in the normalized coordinates.

The HPLC/UV-method for secnidazole determination was proposed by authors before [19] and its specificity in relation to other 5-nitroimidazoles was shown.

We have carried out validation of all developed procedures by such parameters as specificity, recovery, linearity, accuracy, repeatability and intermediate precision according to the approaches offered by us in the variant of the method of standard [20-23].

The validation procedure foresees application of the normalized coordinates. For normalization of the obtained experimental data the reference solution with the concentration of analyte corresponded to its concentration in the end solution to be analysed under the condition of zero losses for the point of $100 \%$ in the normalized coordinates is used. The peak area for reference solution is corrected taking into account the value of recovery $R$, which significance and value has been showed at the preliminary stage of validation, and is used for normalization of peak areas for the model samples.

The range of the methods application is $D=25$ $175 \%$; the number of concentration levels is $g=7$ in constant increments of $25 \%$; as $100 \%$ the mean therapeutic secnidazole concentration in blood $[8,12-15]-8$ $12 \mu \mathrm{g} / \mathrm{ml}$ - is accepted.

The methods validation has been carried out using model samples - the determination procedure and acceptability criteria [20-23] are presented at Fig. 3.

The results of analysis have shown the absence of peaks with the retention time, which is coincident with (or near to) the secnidazole retention time, on the chromatograms of blank-samples for all variants of procedures of analyte isolation from biological liquids that points to the conclusion about acceptable specificity of the developed methods as for the components of biological matrix.

The chromatograms of blood and urine blanksamples and also model samples 1 processed according to the procedure 3 are given on Fig. 4 .

Subjectively, the procedure 1 is characterized by the lowest level of co-extractive substances by the Fig. 2 of TLC-purification, but the procedure 3 has the worst results.

All procedures of sample preparation show the high efficiency of secnidazole isolation both for blood and urine (at the level of $90 \%$ and higher). So high values of recovery give us possibility to calculate the main validation parameters without correction for the value of $R$. Calculation of linearity, accuracy and precision parameters has been carried out both with correction by the $R$ value and without it - absence of such correction does not lead to significant worsening of the method validation parameters. 


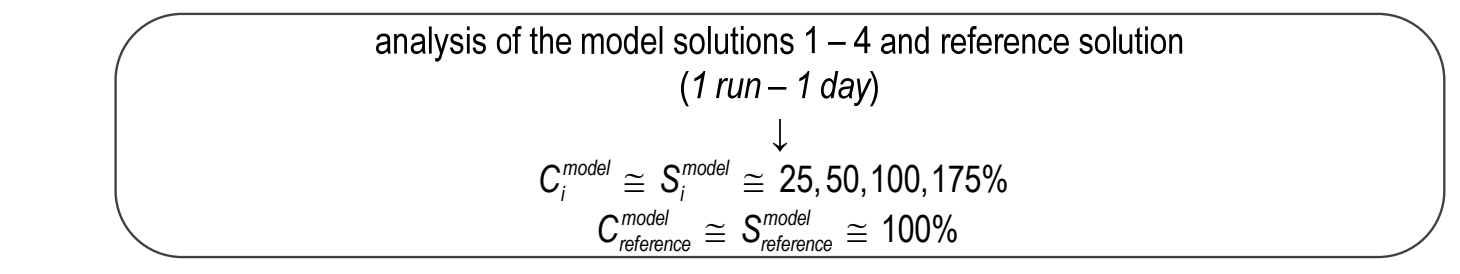

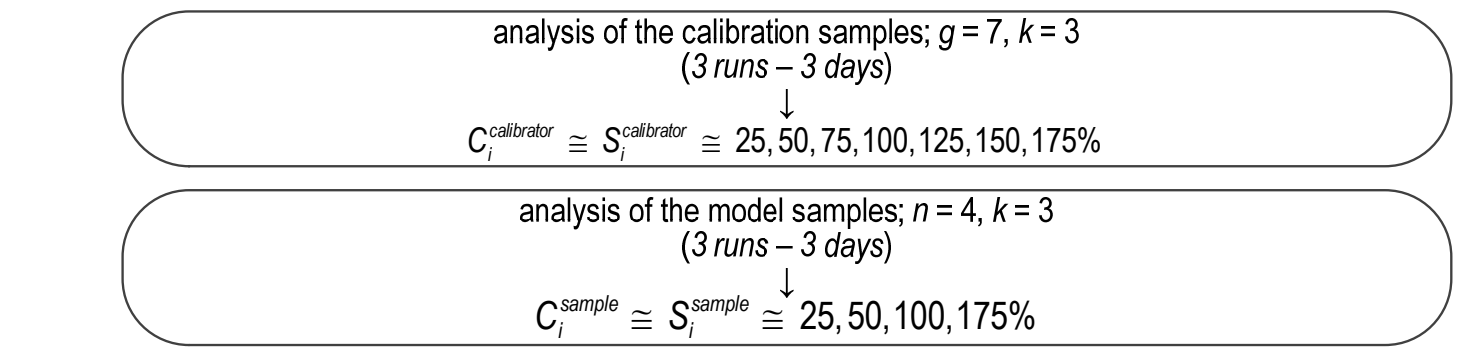

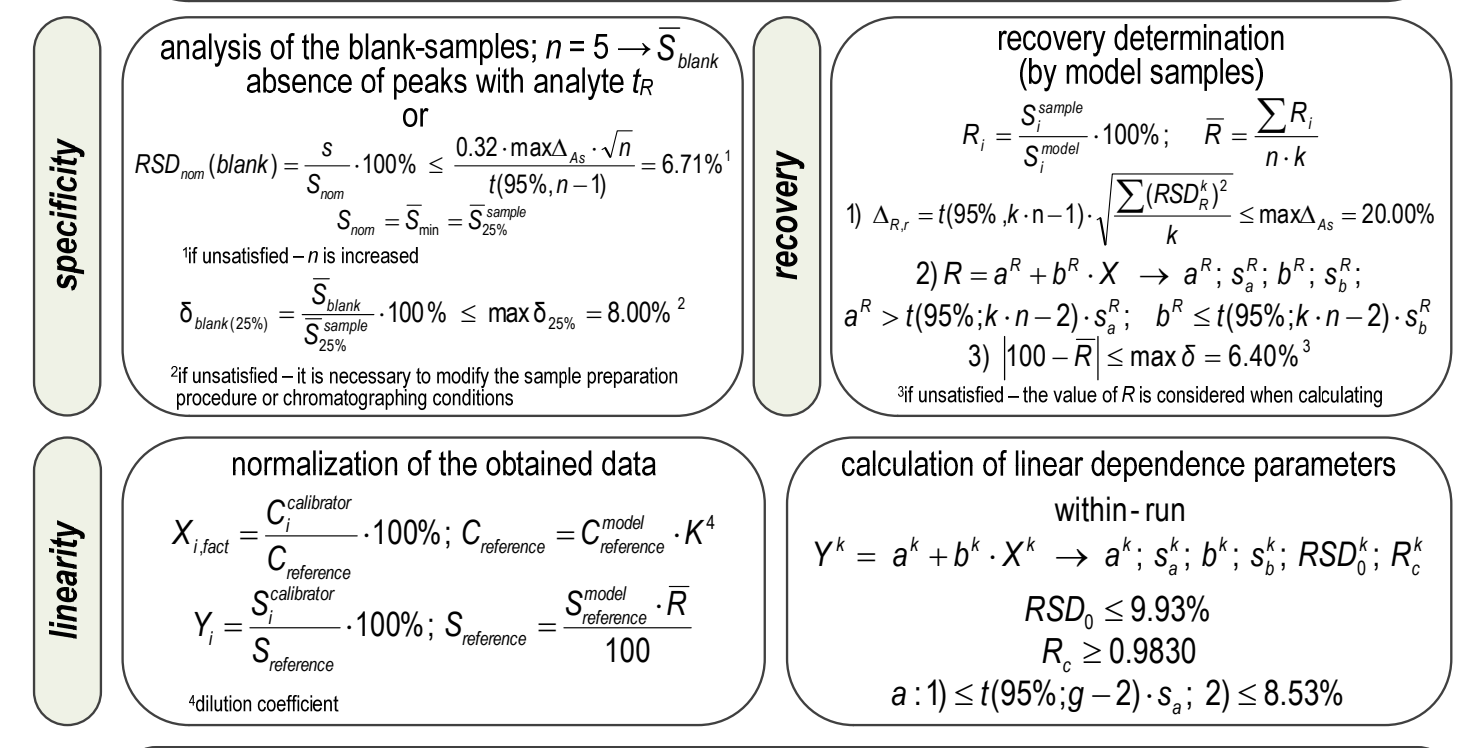

\section{accuracy and precision}

$$
\begin{aligned}
& \begin{array}{c}
\text { within-run } \\
Z_{i}^{k}=\frac{Y_{i}^{k}}{X_{i, \text { fact }}^{k}} \cdot 100 \% \\
\begin{array}{c}
\Delta_{Z}^{k}=t(95 \%, g-1) \cdot R S D_{Z}^{k} \leq \max \Delta_{A s}=20.00 \% \\
\delta^{k}=\left|100-\bar{Z}^{k}\right| \leq \max \delta=6.40 \%
\end{array}
\end{array}
\end{aligned}
$$

Fig. 4. The stages of validation of HPLC-procedures of secnidazole determination in biological liquids using model samples. The total results of validation are presented in Tables $1-3$

Table 1

The total results of recovery determination for HPLC/UV-procedures of secnidazole determination in blood and urine

\begin{tabular}{|c|c|c|c|c|c|}
\hline \multirow{2}{*}{\multicolumn{2}{|c|}{ Parameter }} & \multicolumn{3}{|c|}{ Procedure } & \multirow{2}{*}{$\begin{array}{l}\text { Acceptability } \\
\text { criterion }\end{array}$} \\
\hline & & 1 & 2 & 3 & \\
\hline \multirow{5}{*}{$\begin{array}{l}7 \\
0 \\
\vdots \\
0\end{array}$} & $\bar{R}$ & 91.73 & 91.22 & 96.38 & - \\
\hline & $\Delta_{R, r}$ & 6.33 & 6.45 & 9.59 & $\leq 20.00 \%$ \\
\hline & $b^{R} / s_{b}^{R}$ & $0.02 / 0.02$ & $0.03 / 0.02$ & $0.01 / 0.03$ & $b^{R} \leq 1.812 \cdot s_{b}^{R}$ \\
\hline & $a^{R} / s_{a}^{R}$ & $89.91 / 1.65$ & $88.94 / 1.60$ & $95.79 / 2.64$ & $a^{R}>1.812 \cdot s_{a}^{R}$ \\
\hline & $|100-\bar{R}|$ & 8.27 & 8.78 & 3.62 & $\leq 6.40 \%$ \\
\hline \multirow{5}{*}{$\stackrel{\Xi}{\Xi}$} & $\bar{R}$ & 95.54 & 92.26 & 96.64 & - \\
\hline & $\Delta_{R, r}$ & 6.45 & 8.14 & 8.07 & $\leq 20.00 \%$ \\
\hline & $b^{R} / s_{b}^{R}$ & $-0.03 / 0.01$ & $0.02 / 0.02$ & $0.01 / 0.02$ & $b^{R} \leq 1.812 \cdot s_{b}^{R}$ \\
\hline & $a^{R} / s_{a}^{R}$ & $97.96 / 1.49$ & $90.60 / 2.10$ & $95.96 / 2.22$ & $a^{R}>1.812 \cdot s_{a}^{R}$ \\
\hline & $|100-\bar{R}|$ & 4.46 & 7.74 & 3.36 & $\leq 6.40 \%$ \\
\hline
\end{tabular}




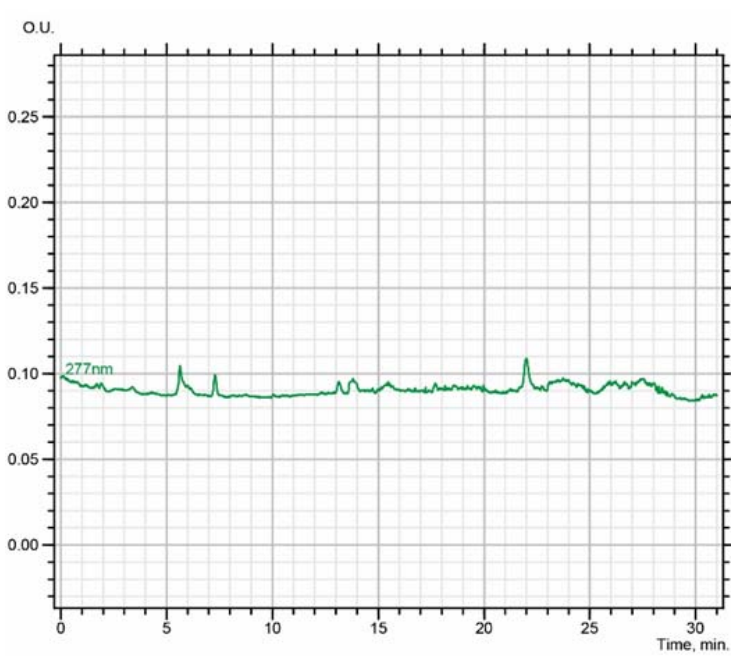

$a$

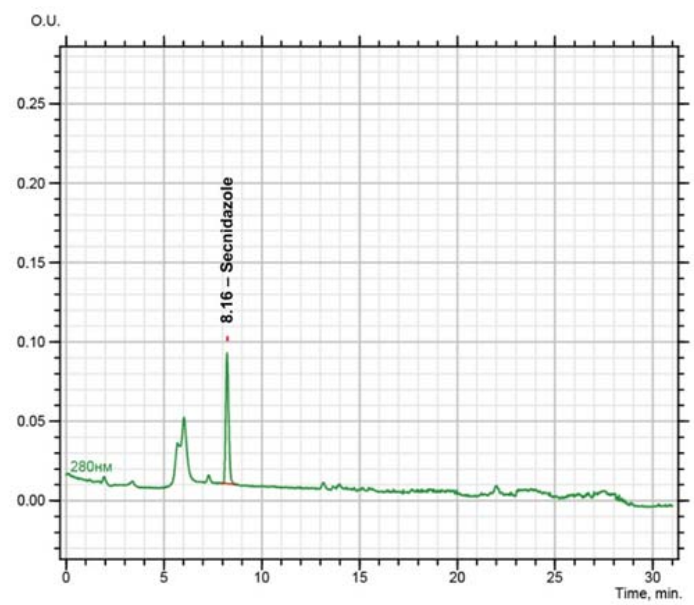

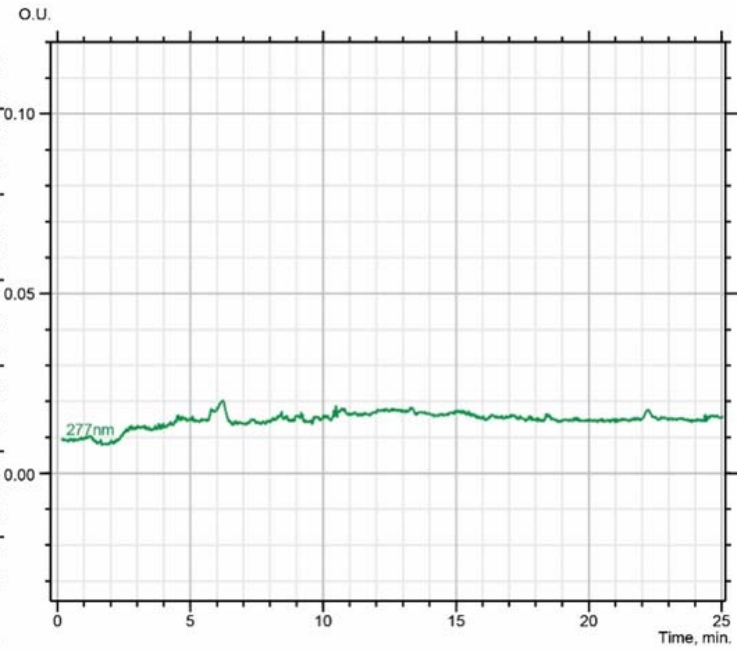

$b$

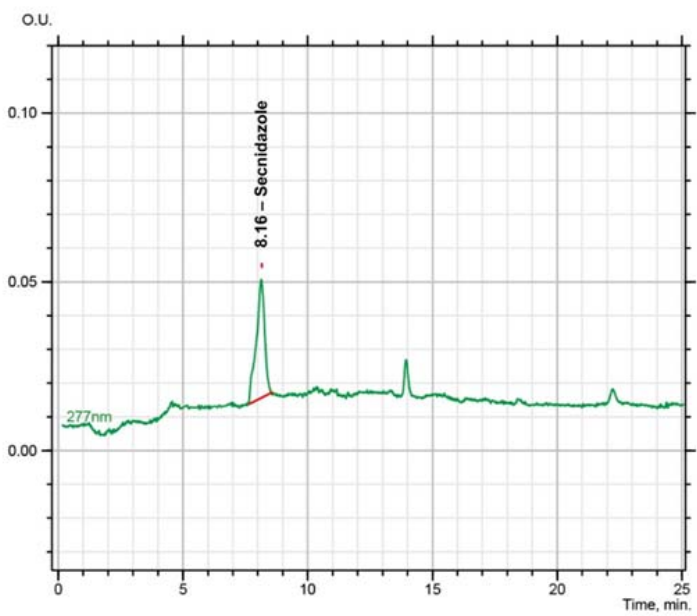

d

Fig. 2. The chromatograms of blood and urine blank- and model samples: $a$ - procedure 3, blood, blank-sample; $b$-procedure 3 , urine, blank-sample; $c$ - procedure 3 , blood, model sample $1 ; d$-procedure 3 , urine, model sample 1

Table 2

The total results of linearity verification for HPLC/UV-procedures of secnidazole determination in blood and urine

\begin{tabular}{|c|c|c|c|c|c|c|c|c|}
\hline \multirow{3}{*}{\multicolumn{2}{|c|}{ Parameter }} & \multicolumn{6}{|c|}{ Biological liquid } & \multirow{3}{*}{$\begin{array}{c}\text { Acceptability } \\
\text { criterion }\end{array}$} \\
\hline & & \multicolumn{3}{|c|}{ blood } & \multicolumn{3}{|c|}{ urine } & \\
\hline & & run 1 & run 2 & run 3 & run 1 & run 2 & run 3 & \\
\hline \multicolumn{2}{|c|}{1} & 2 & 3 & 4 & 5 & 6 & 7 & 8 \\
\hline \multirow{6}{*}{ 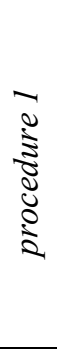 } & $b^{k}$ & 0.953 & 0.983 & 0.982 & 0.939 & 0.973 & 0.982 & \\
\hline & $s_{b}^{k}$ & 0.017 & 0.017 & 0.022 & 0.014 & 0.019 & 0.016 & \\
\hline & $a^{k}$ & 1.605 & -1.065 & -0.715 & 5.525 & 2.494 & 0.069 & \multirow{2}{*}{$\begin{array}{c}a \leq 2.015 \cdot s_{a} \\
a \leq 8.53 \%\end{array}$} \\
\hline & $s_{a}^{k}$ & 1.888 & 1.896 & 2.417 & 1.536 & 2.164 & 1.789 & \\
\hline & $R S D_{0}^{k}$ & 2.234 & 2.243 & 2.859 & 1.817 & 2.560 & 2.117 & $\leq 9.93 \%$ \\
\hline & $R_{c}^{k}$ & 0.9992 & 0.9993 & 0.9988 & 0.9995 & 0.9990 & 0.9993 & $\geq 0.9830$ \\
\hline \multirow{6}{*}{ 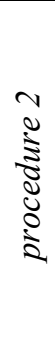 } & $b^{k}$ & 0.940 & 0.963 & 0.936 & 0.948 & 0.963 & 0.945 & \\
\hline & $s_{b}^{k}$ & 0.023 & 0.026 & 0.017 & 0.024 & 0.026 & 0.021 & \\
\hline & $a^{k}$ & 1.310 & 0.582 & 1.294 & 1.387 & 1.703 & 1.534 & \multirow{2}{*}{$\begin{array}{c}a \leq 2.015 \cdot s_{a} \\
a \leq 8.53 \%\end{array}$} \\
\hline & $s_{a}^{k}$ & 2.580 & 2.872 & 1.932 & 2.721 & 2.960 & 2.391 & \\
\hline & $R S D_{0}^{k}$ & 3.053 & 3.398 & 2.286 & 3.219 & 3.502 & 2.829 & $\leq 9.93 \%$ \\
\hline & $R_{c}^{k}$ & 0.9985 & 0.9982 & 0.9991 & 0.9984 & 0.9981 & 0.9987 & $\geq 0.9830$ \\
\hline
\end{tabular}




\begin{tabular}{|c|c|c|c|c|c|c|c|c|}
\hline \multicolumn{2}{|c|}{1} & 2 & 3 & 4 & 5 & 6 & 7 & \multicolumn{5}{c|}{ Continuation of Table 2 } \\
\hline \multirow{4}{*}{$\approx$} & $b^{k}$ & 0.936 & 0.920 & 0.948 & 0.933 & 0.924 & 0.950 & \\
\cline { 2 - 9 } & $s_{b}^{k}$ & 0.020 & 0.014 & 0.015 & 0.019 & 0.011 & 0.014 & \\
\cline { 2 - 9 } & $a^{k}$ & 0.299 & 1.597 & -1.321 & 0.409 & 1.322 & -1.306 & $a \leq 2.015 \cdot s_{a}$ \\
\cline { 2 - 9 } & $s_{a}^{k}$ & 2.269 & 1.589 & 1.664 & 2.134 & 1.248 & 1.526 & $a \leq 8.53 \%$ \\
\cline { 2 - 9 } & $R S D_{0}^{k}$ & 2.684 & 1.880 & 1.968 & 2.524 & 1.476 & 1.805 & $\leq 9.93 \%$ \\
\cline { 2 - 9 } & $R_{c}^{k}$ & 0.9988 & 0.9994 & 0.9994 & 0.9990 & 0.9996 & 0.9995 & $\geq 0.9830$ \\
\hline
\end{tabular}

Table 3

The total results of precision and accuracy determination for HPLC/UV-procedures of secnidazole determination in blood and urine

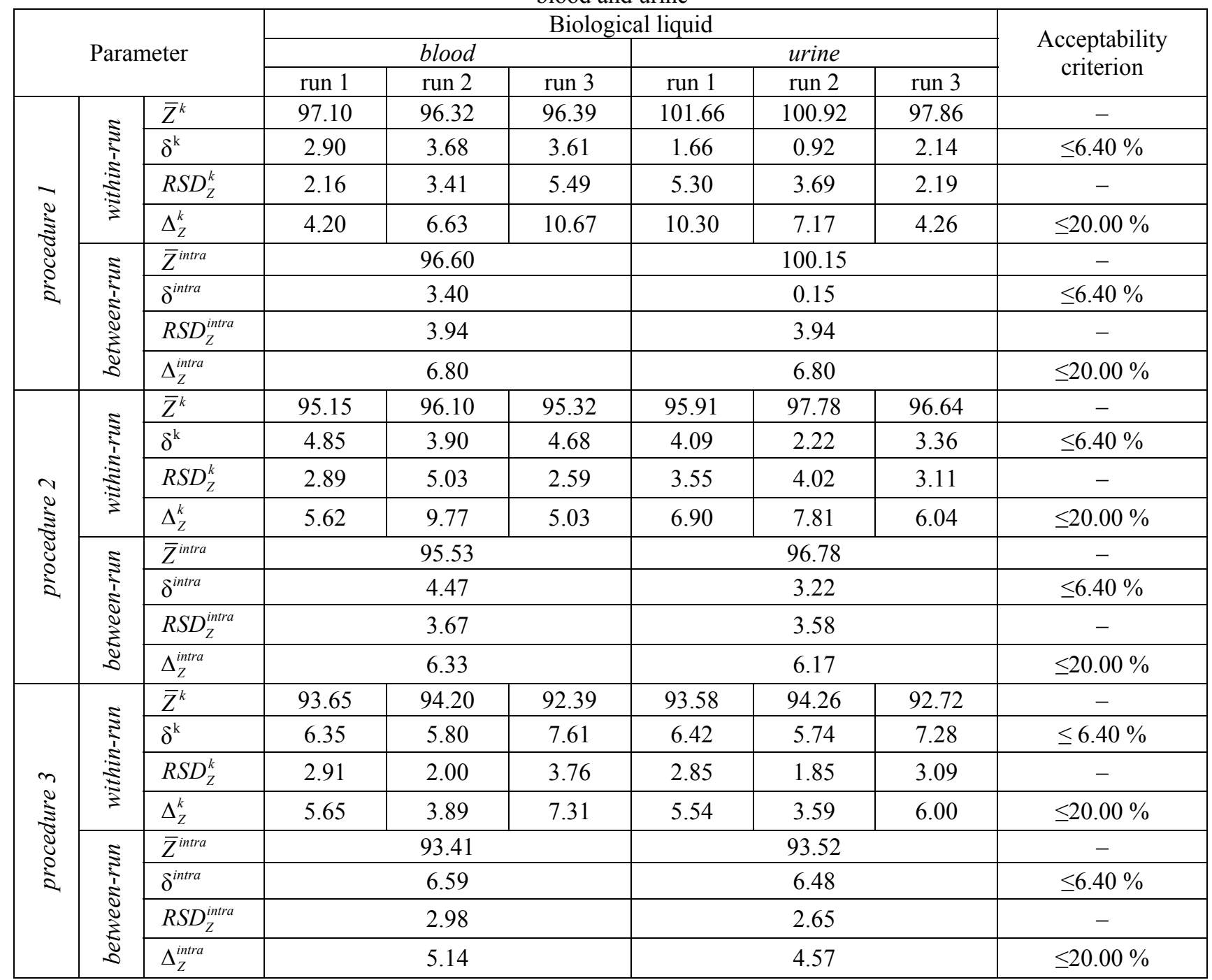

All examined procedures are characterized by the acceptable parameters of linearity; the calibration curves by runs are presented on Fig. 5 . In all cases the values of $a^{k}, R S D_{0}^{k}, R_{c}^{k}$ are satisfied the acceptability criteria.
Accuracy and precision have been determined as within-run and between-run parameters, and we may not highlight the best procedure by the values of systematic and random errors, but according to the number of steps in the procedure of sample preparation the procedure 3 is optimal. 

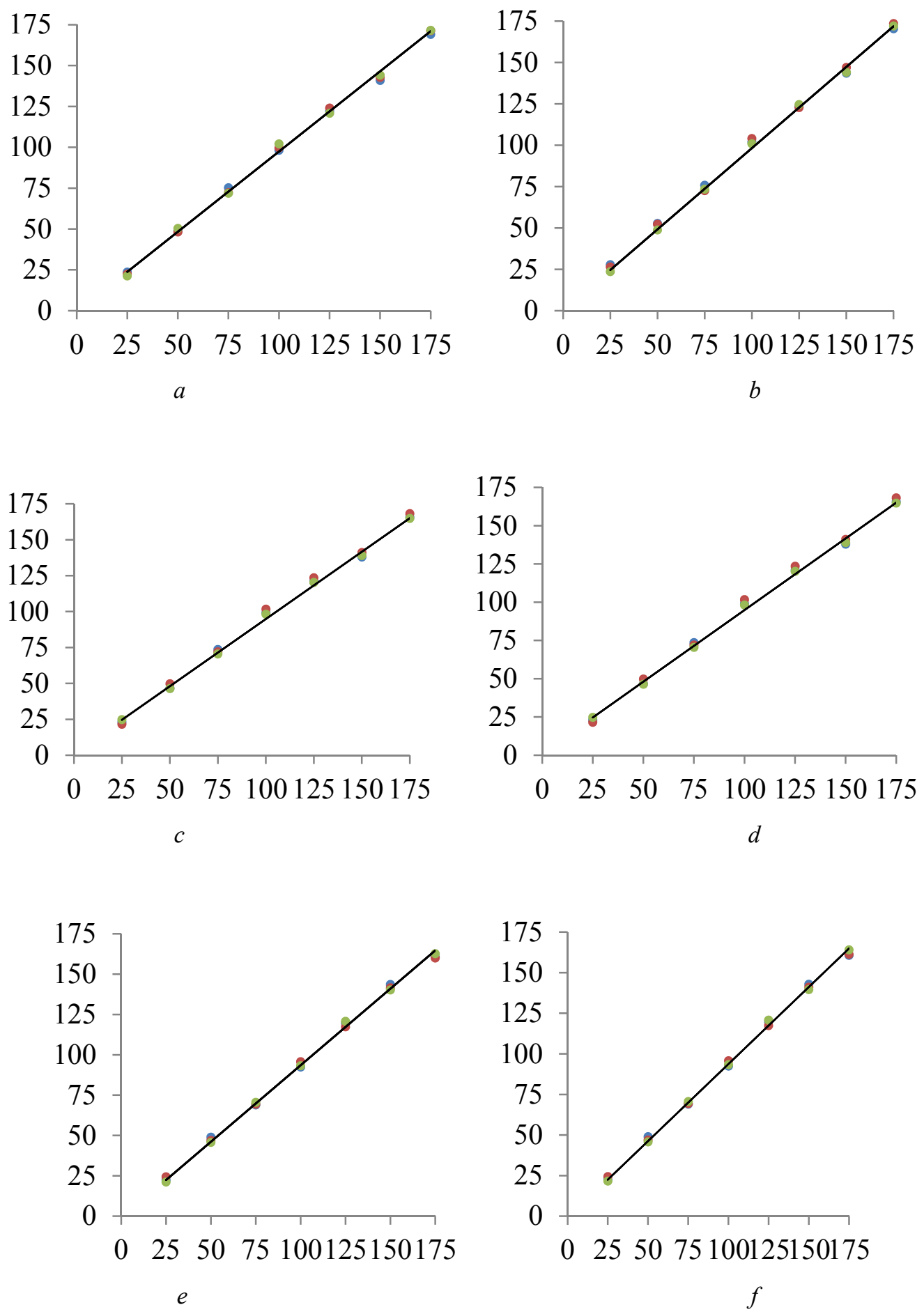

Fig. 5. The calibration curves for HPLC/UV-procedures of secnidazole determination in blood and urine: $a$ - procedure 1, blood; $b$-procedure 1 , urine; $c$-procedure 2 , blood; $d$-procedure 2 , urine; $e$ - procedure 3 , blood; $f$-procedure 3 , urine

\section{Conclusions from the conducted research} and prospects for further development of this field

The set of HPLC-procedures of secnidazole quantitative determination in blood and urine has been developed. proposed:

1. Three types of sample preparation have been

1) liquid-liquid extraction with organic solvents immiscible with water,

2) amphiphylic solvents extraction and salting-out with ammonium sulphate,
3) complex application of liquid-liquid extraction with organic solvents immiscible with water and amphiphylic solvents extraction with salting-out. All procedures are effective by the recovery parameter, but the second way of extraction is optimal.

2. Validation of the developed procedures has been carried out and it has been set that isopropanol application in the acid medium $(\mathrm{pH}=2)$ is optimal for secnidazole determination in biological liquids - the extraction efficiency is maximal and equal to $\sim 97 \%$, and parameters of linearity, accuracy and precision are optimal. 


\section{References}

1. Brook I. Spectrum and treatment of anaerobic infections // Journal of Infection and Chemotherapy. 2016. Vol. 22 , Issue 1. P. 1-13. doi: http://doi.org/10.1016/j.jiac.2015.10.010

2. Upcroft P., Upcroft J. A. Drug Targets and Mechanisms of Resistance in the Anaerobic Protozoa // Clinical Microbiology Reviews. 2001. Vol. 14, Issue 1. P. 150-164. doi: http://doi.org/10.1128/cmr.14.1.150-164.2001

3. Rose M. D., Bygrave J., Sharman M. Effect of cooking on veterinary drug residues in food Part 9 Nitroimidazoles // The Analyst. 1999. Vol. 124, Issue 3. P. 289-294. doi: http://doi.org/10.1039/a809062i

4. Sobel R., Sobel J. D. Metronidazole for the treatment of vaginal infections // Expert Opinion on Pharmacotherapy. 2015. Vol. 16, Issue 7. P. 1109-1115. doi: http://doi.org/10.1517/14656566.2015.1035255

5. Samuelson J. Why Metronidazole Is Active against both Bacteria and Parasites // Antimicrobial Agents and Chemotherapy. 1999. Vol. 43, Issue 7. P. 1533-1541. doi: http://doi.org/10.1128/aac.43.7.1533

6. Freeman C. D., Klutman N. E., Lamp K. C. Metronidazole. A therapeutic review and update // Drugs. 1997. Vol. 54. P. 679-708. doi: http://doi.org/10.2165/00003495-199754050-00003

7. Commission Regulation (EU) No. 37/2010 of 22 December 2009 on pharmacologically active substances and their classification regarding maximum residue limits in foodstuffs of animal origin // Official Journal of the European Union. 2010. L15. P. 1-72.

8. Pharmacokinetics and Pharmacodynamics of the Nitroimidazole Antimicrobials / Lamp K. C. et. al. // Clinical Pharmacokinetics. 1999. Vol. 36, Issue 5. P. 353-373. doi: http://doi.org/10.2165/00003088-199936050-00004

9. Gillis J. C., Wiseman L. R. Secnidazole. A review of its antimicrobial activity, pharmacokinetic properties and therapeutic use in the management of protozoal infections and bacterial vaginosis // Drugs. 1996. Vol. 51, Issue 4. P. 621-638. doi: http://doi.org/10.2165/00003495-199651040-00007

10. Spectrophotometric and HPLC determination of secnidazole in pharmaceutical tablets / El Walily A. F. M. et. al. // Journal of Pharmaceutical and Biomedical Analysis. 2000. Vol. 22, Issue 6. P. 887-897. doi: http://doi.org/10.1016/s0731-7085(99)00290-3

11. Sun H. W., Wang F. C., Ai L. F. Simultaneous determination of seven nitroimidazole residues in meat by using HPLCUV detection with solid-phase extraction // Journal of Chromatography B: Analytical Technologies in the Biomedical and Life Sciences. 2007. Vol. 857, Issue 2. P. 296-300. doi: http://doi.org/10.1016/j.jchromb.2007.07.039

12. Rapid and selective analysis of secnidazole in human plasma using high-performance liquid chromatography with ultraviolet detection / Ravi S. K. et. al. // Journal of Chromatography B: Biomedical Sciences and Applications. 1997. Vol. 691, Issue 1. P. 208-211. doi: http://doi.org/10.1016/s0378-4347(96)00419-7

13. Determination of secnidazole in human plasma by high-performance liquid chromatography with UV detection and its application to the bioequivalence studies / Li X. et. al. // Biomedical Chromatography. 2007. Vol. 21, Issue 3. P. 304-309. doi: http://doi.org/10.1002/bmc. 758

14. Evaluation of the Bioequivalence and Pharmacokinetics of Two Formulations of Secnidazole after Single Oral Administration in Healthy Volunteers / Zhu D. et. al. // Arzneimittelforschung. 2011. Vol. 57, Issue 11. P. 723-726. doi: http://doi.org/10.1055/s-0031-1296674

15. Secnidazole concentrations in plasma and crevicular fluid after a single oral dose / Tenenbaum H. et. al. // Journal of Clinical Periodontology. 1993. Vol. 20, Issue 7. P. 505-508. doi: http://doi.org/10.1111/j.1600-051x.1993.tb00398.x

16. Mitrowska K., Antczak M. Development and validation of a liquid chromatography with tandem mass spectrometry method for the determination of nitroimidazole residues in beeswax // Journal of Separation Science. 2017. Vol. 40, Issue 5. P. 1158-1166. doi: http://doi.org/10.1002/jssc. 201600928

17. High-throughput method for the determination of nitroimidazoles in muscle samples by liquid chromatography coupled to mass spectrometry / Rúbies A. et. al. // Analytical and Bioanalytical Chemistry. 2015. Vol. 407, Issue 15. P. 4411-4421. doi: http://doi.org/10.1007/s00216-014-8436-x

18. Azarova I. N., Baram G. I. Primenenie perhlorata litiya v obraschenno-fazovoy vyisokoeffektivnoy zhidkostnoy hromatografii aminosoedineniy // Sorbtsionnyie i hromatograficheskie protsessyi. 2014. Vol. 14, Issue 1. P. 858-867.

19. Development and validation of HPLC/UV-procedure of secnidazole determination / Shovkova O. V. et. al. // Journal of Organic and Pharmaceutical Chemistry. 2018. Vol. 16, Issue 3 (63). P. 30-38. doi: http://doi.org/10.24959/ophcj.18.948

20. Klimenko L. Yu. The integrated approach to development and validation of the procedures of analytes quantification in biological fluids for chemical and toxicological analysis: DSc thesis. Kharkiv, 2016. 816 p.

21. Moffat A. C., Osselton M. D., Widdop B. Clarke's analysis of drugs and poisons in pharmaceuticals, body fluids and postmortem material: 4th ed. London: Pharmaceutical Press, 2011. 2609 p.

22. Klimenko L. Yu. Development of approaches to determination of linearity, accuracy and precision of UVspectrophotometric methods of quantitative determination by the method of standard in forensic and toxicological analysis // Farmatsyia Kazakhstana. 2014. Vol. 4, Issue 155. P. 31-35.

23. Klimenko L. Yu., Trut S. M., Poluyan S. M. Determination of validation characteristics of UV-spec-trophotometric method of doxylamine quantitative determination in blood in the variant of the method of standard // News of Pharmacy. 2014. Vol. 2, Issue 78. P. 53-58. doi: http://doi.org/10.24959/nphj.14.1969

Дата надходження рукопису 30.10.2018

Oksana Shovkova, assistant, Department of Biological Chemistry, National University of Pharmacy, Pushkinska str., 53, Kharkov, Ukraine, 61002

E-mail: kseniashovkova@gmail.com

Lina Klimenko, Doctor of Pharmaceutical Sciences, Associate Professor, Department of Analytical Chemistry National University of Pharmacy, Pushkinska str., 53, Kharkov, Ukraine, 61002

E-mail: lina_klimenko@nuph.edu.ua

Zoia Shovkova, PhD, Associate Professor, Department of Drug and Analytical Toxicology, National University of Pharmacy, Pushkinska str., 53, Kharkov, Ukraine, 61002

E-mail: toxchem@nuph.edu.ua

Olena Mykytenko, PhD, Associate Professor, Department of Analytical Chemistry, National University of Pharmacy, Pushkinska str., 53, Kharkov, Ukraine, 61002

E-mail: mikitenko-elena@ukr.net 